\title{
Study of some toxicological aspects of Alfa-cypermethrin in rabbits
}

\author{
Dh. R.H. Al-Fetly \\ N. K. M. Al-Nakeeb \\ Coll. of Vet. Med./ Univ. of AL-Qadisiya
}

\begin{abstract}
This study was conducted to evaluate the immediate alterations that occur in rabbits after acute toxicity with single oral dose of cypermethrin. Twenty one rabbits were randomly divided into three equal groups: treated groups (A1), (A2) and control group used in this study. Groups (A1), (A2) received orally cypermethrin in dose of $(25,50 \mathrm{mg} / \mathrm{kg}$ body weight) respectively, While control group received normal saline at same time. Most obvious clinical sings in the treated groups were Restlessness, salivation, licking of legs and face, frequent urination, muscular tremor, incoordination, and ataxia appeared in dose dependent manner. In addition, significantly increased in respiratory rate and heart rate in treated groups compared with control group and appeared petechial hemorrhage and congestion in the conjunctiva in treated groups. The blood samples were taking to evaluate some of blood parameters includes (RBC counts, WBC counts, PLT counts, Hb concentration, PCV, RBCs indices (MCV, MCH, MCHC, RDW -CV and RDW - SD), PDW, MPV, P-LCR and some biochemical study as ALT and AST. Two rabbits from each group were killed to evaluate the histopathological alteration in liver. The statistical analysis revealed that there were significant decreased in $\mathrm{RBC}$ counts and $\mathrm{Hb}$ concentration $(\mathrm{P}<0.05)$ in treated groups $(\mathrm{A} 1),(\mathrm{A} 2)$ as compared with control group. The PCV percentage, platelet counts and MCHC values revealed significant decreased $(\mathrm{P}<0.05)$ between group (A2) and control group. The RDW-SD, RDW-CV valves were significantly increased $(\mathrm{p}<0.05)$ between group $(\mathrm{A} 1)$ and control group. Other parameter studied did not show significant differences between treated groups and control group. The statistical analysis revealed that the levels of ALT and AST were significantly elevated $(\mathrm{P}<0.05)$ in $(\mathrm{A} 1$ and $\mathrm{A} 2)$ groups as compared with control group. In gross appearance there were petechial hemorrhage and erosion of liver parenchyma. Histopathological study revealed that there were engorgement of hepatic vein with presence of extravasated RBCs between the hepatocytes in group (A1), while group (A2) the hepatocytes undergo atrophy and severe necrosis and destruction with infiltration of polymorphnuclear leukocytes and engorgement of some portal trait with bile secretion.
\end{abstract}

\section{Introduction}

Pyrethrin and pyrethroid insecticides are effective against a variety of insect pests on pets, livestock and other animals and are readily available for home, farm and garden use (1). They are available in shampoos, sprays, powders, flea collars, dips, spot-on, pour-on, $(2,3)$.Cypermethrin is a type II pyrethroid (synthetic pyrethrins) that contain an Alpha- cyano group increases insecticidal potency ( 1). Cypermethrin is toxic to nervous system it also suppresses the immune system and classified as possible human carcinogen because it causes an increase in the frequency of lung tumors in female mice (4).All animals may exhibit paresthesia following application of apyrethrin or pyrethroid product. In cattle may become restless and act uncomfortable twitch the skin on their backs after application of a pyrethroid pour-on product (1). While clinical signs like increased urination licking of legs, jerky movement, ataxia, incoordination, staggering and dizziness have been reported in rabbits after injected intraperitoneally cypermethrin (5).Longterm feeding studies with laboratory animals have shown that cypermethrin causes adverse effects; in mice it caused reduced weight gain, mild anemia and increases liver weight (4). This project was designed to investigate symptoms and alterations in some blood parameters and some biochemical parameters after induced of single oral dose of cypermethrin and study the gross and histopathological lesion in liver due cypermthrin toxicity. 


\section{Materials and methods}

Twenty one rabbits were used in this study. After seven days of acclimatization the rabbits were randomly divided into three equal groups: treated group (A1), treated group (A2) and control group, with seven rabbits in each group. Rabbits of groups (A1) and (A2) were received oral cypermethrin in dose of $(25,50 \mathrm{mg} / \mathrm{kg}$ body weight) respectively, while control group received normal saline at same time. Treated animals were monitoring at least once a day to recording the suspected clinical signs the study continued for ten days. The blood samples with anticoagulant were taking to evaluate some of blood parameters include (RBC counts, WBC counts, PLT counts, $\mathrm{Hb}$ concentration, PCV, RBC indices (MCV, $\mathrm{MCH}, \mathrm{MCHC}$, RDW - CV(RBC distribution width-CV) and RDW $\mathrm{SD}(\mathrm{RBC}$ distribution width-SD) ) ,

In present study, the onset of clinical signs after 5-10 minute While the nervous signs recorded at 50 minute. Most obvious clinical signs in group (A1) were, restlessness, salivation, licking of legs and face, little incoordination, Ataxia, muscular tremor finely depression while in group (A2) the same clinical signs appear but more severely Table (1). Congestion of conjunctiva and petechial hemorrhage (Figure1a). In addition, the recorded significant increase in heart rate and respiratory rate at a level $(\mathrm{p}<0.05)$ between (A1), (A2) groups and control group Table (2) Theses clinical signs were subsides during (90) minute. The statistical analysis revealed that there were significant decreased in $\mathrm{RBC}$ counts and $\mathrm{Hb}$ concentration $(\mathrm{P}<0.05)$ in treated groups (A1), (A2) as compared with control group. The PCV percentage and $\mathrm{MCHC}$ values were revealed significant decreased $(\mathrm{P}<0.05)$ between group (A2) and control group and also the MCHC values significantly differences between (A1) and (A2) groups. The RDW-SD and RDW-CV valves was significantly increased $(\mathrm{p}<0.05)$ between group (A1) and control group, and also RDW-CV the was significant
PDW(Platelet distribution width), MPV (mean platelet volume), P-LCR(large platelet ratio) used automated hematology analyzer KX-21 N ( Sysmex corporation, Kobe, Japan). Then, blood samples with anticoagulant centrifuged immediately after collection for separation of plasma and utilized for the estimation of aspartate aminotransferase (AST) and alanine aminotransferase( ALT) $(6,7)$. Two rabbits from each group were killed to evaluate the histopathological alteration in liver. Tissue samples taken from liver were fixed in $10 \%$ buffered formalin and using routine methods and section of 5 micro meter thickness were cut and stained with hematoxylin and eosin $(8,9)$. Statistical analysis was done using SPSS (version10); the data were analyzed statistically using one way ANOVA with LSD to establish significant differences among groups.

\section{Results}

differences between treated groups. While the WBC counts revealed non significant decreased in treated groups compared with control group. The platelet counts significantly decreased at level $(\mathrm{P}<0.05)$ between treated group (A2) and control group, While the PDW, MPV revealed non significant increased in treated groups compared with control group (Table 3). The statistical analysis revealed that the levels of ALT and AST were significantly elevated $(\mathrm{P}<0.05)$ in $(\mathrm{A} 1$ and $\mathrm{A} 2)$ groups as compared with control group (Table 3 ). In gross appearance there were petechial hemorrhage and erosion of liver parenchyma and patchy pale areas in liver parenchyma (Figure 1b). Histopathological study revealed that there were engorgement of hepatic vein with presence of extravasated RBCs between the hepatocytes in group (A1) (Figure 2), while group (A2) appeared necrosis of hepatocytes with infiltration of polymorphnuclear leukocytes (Figure $3)$. The hepatocytes undergo atrophy and severe necrosis and destruction (Figure 4 and 5) and engorgement of some portal trait with bile secretion (Figure 6). 
Table (1): The clinical signs that occur after cypermethrin toxicity in rabbits.

\begin{tabular}{|l|l|l|l|}
\hline & \multicolumn{1}{|c|}{ Aroups } & \multicolumn{1}{|c|}{ A2 } \\
\hline 1 & Clinical signs & \multicolumn{1}{|c|}{$\begin{array}{l}\text { Anjunctiva } \\
\text { Mild }\end{array}$} & $\begin{array}{l}\text { Severe conjunctival congestion and } \\
\text { petechial hemorrhage. }\end{array}$ \\
\hline 2 & Nervous signs & $\begin{array}{l}\text { Ataxia, incoordination, } \\
\text { muscular tremor, finely } \\
\text { Depression. }\end{array}$ & $\begin{array}{l}\text { Severe ataxia, incoordination unable to } \\
\text { move and muscular tremor finely } \\
\text { depression }\end{array}$ \\
\hline 3 & $\begin{array}{l}\text { Abnormal } \\
\text { behavior }\end{array}$ & $\begin{array}{l}\text { Restlessness, Salivation, } \\
\text { licking of face and legs. }\end{array}$ & $\begin{array}{l}\text { Restlessness, Profuse salivation,licking of } \\
\text { face and legs, frequent urination,grunting } \\
\text { sound. }\end{array}$ \\
\hline
\end{tabular}

A1: represent group that treated with $25 \mathrm{mg} / \mathrm{kg}$ cypermethrin

A2: represent group that treated with $50 \mathrm{mg} / \mathrm{kg}$ cypermethrin

Table (2): The clinical assessment of rabbits suffering from cypermethrin toxicity. The results represent Mean \pm SE.

\begin{tabular}{|c|l|c|c|c|}
\hline $\mathrm{N}$ & $\begin{array}{l}\text { llinical } \\
\text { assessment }\end{array}$ & \multicolumn{1}{|c|}{ A1 Group } & A2 Group & Control Group \\
\hline 1 & Heart Rate & $198.29 \pm 7.85 \mathrm{~A}$ & $198.57 \pm 22.44 \mathrm{~A}$ & $124.57 \pm 3.62 \mathrm{~B}$ \\
\hline 2 & $\begin{array}{l}\text { Respiratory } \\
\text { Rate }\end{array}$ & $175.43 \pm 11.16 \mathrm{~A}$ & $185.71 \pm 25.93 \mathrm{~A}$ & $83.00 \pm 4.71 \mathrm{~B}$ \\
\hline
\end{tabular}

Means within a row with different letter differ significantly $(\mathrm{p}<0.05)$ between groups.

Table (3): Hematological and biochemical parameters in rabbits treated with different doses of cypermethrin.

\begin{tabular}{|c|c|c|c|c|}
\hline $\mathrm{N}$ & Groups & A1 Group & A2 Group & Control Group \\
\hline 1 & WBC $10^{3} / \mu \mathrm{L}$ & $5.38 \pm 0.73$ & $4.27 \pm 0.38$ & $6.05 \pm 1.04$ \\
\hline 2 & $\mathrm{RBC} 10^{6} / \mu \mathrm{L}$ & $5.06 \pm 0.17 \mathrm{~A}$ & $4.84 \pm 0.27 \mathrm{~A}$ & $5.78 \pm 0.27 \mathrm{~B}$ \\
\hline 3 & $\mathrm{Hb} \mathrm{g} / \mathrm{dL}$ & $10.49 \pm 0.48 \mathrm{~A}$ & $9.86 \pm 0.58 \mathrm{~A}$ & $12.07 \pm 0.47 \mathrm{~B}$ \\
\hline 4 & $\mathrm{PCV} \%$ & $34.03 \pm 1.39 \mathrm{AB}$ & $33.51 \pm 1.91 \mathrm{~A}$ & $39.03 \pm 2.01 \mathrm{~B}$ \\
\hline 5 & MCV fL & $67.13 \pm 0.84$ & $69.39 \pm 1.48$ & $67.46 \pm 0.73$ \\
\hline 6 & $\mathrm{MCH}$ pg & $20.67 \pm 0.58$ & $20.39 \pm 0.39$ & $20.91 \pm 0.35$ \\
\hline 7 & $\mathrm{MCHC}$ g/dL & $30.81 \pm 0.57 \mathrm{~B}$ & $29.43 \pm 0.11 \mathrm{~A}$ & $31.06 \pm 0.45 \mathrm{~B}$ \\
\hline 8 & RDW-SD fL & $37.13 \pm 1.41 \mathrm{~A}$ & $35.20 \pm 1.03 \mathrm{AB}$ & $33.87 \pm 0.53 \mathrm{~B}$ \\
\hline 9 & RDW-CV \% & $14.74 \pm 0.85 \mathrm{~A}$ & $12.70 \pm 0.44 \mathrm{~B}$ & $12.89 \pm 0.44 \mathrm{~B}$ \\
\hline 10 & $\mathrm{PLT} 10^{3} / \mu \mathrm{L}$ & $449.43 \pm 120.53 \mathrm{AB}$ & $289.29 \pm 79.94 \mathrm{~A}$ & $602.57 \pm 83.09 \mathrm{~B}$ \\
\hline 11 & PDW fL & $10.67 \pm 1.25$ & $8.73 \pm 0.37$ & $8.43 \pm 0.32$ \\
\hline 12 & MPV fL & $7.77 \pm 0.37$ & $7.40 \pm 0.30$ & $7.21 \pm 0.29$ \\
\hline 13 & P-LCR \% & $13.09 \pm 3.58$ & $9.19 \pm 1.45$ & $9.91 \pm 2.42$ \\
\hline 14 & ALT U/L & $68.37 \pm 2.60 \mathrm{~A}$ & $71.31 \pm 14.70 \mathrm{~A}$ & $33.71 \pm 1.45 \mathrm{~B}$ \\
\hline 15 & AST U/L & $54.71 \pm 1.23 \mathrm{~A}$ & $61.31 \pm 7.78 \mathrm{~A}$ & $25.95 \pm 0.42 \mathrm{~B}$ \\
\hline
\end{tabular}

Values represent Mean \pm SE.

Means within a row with different letter differ significantly $(\mathrm{p}<0.05)$ between groups. 

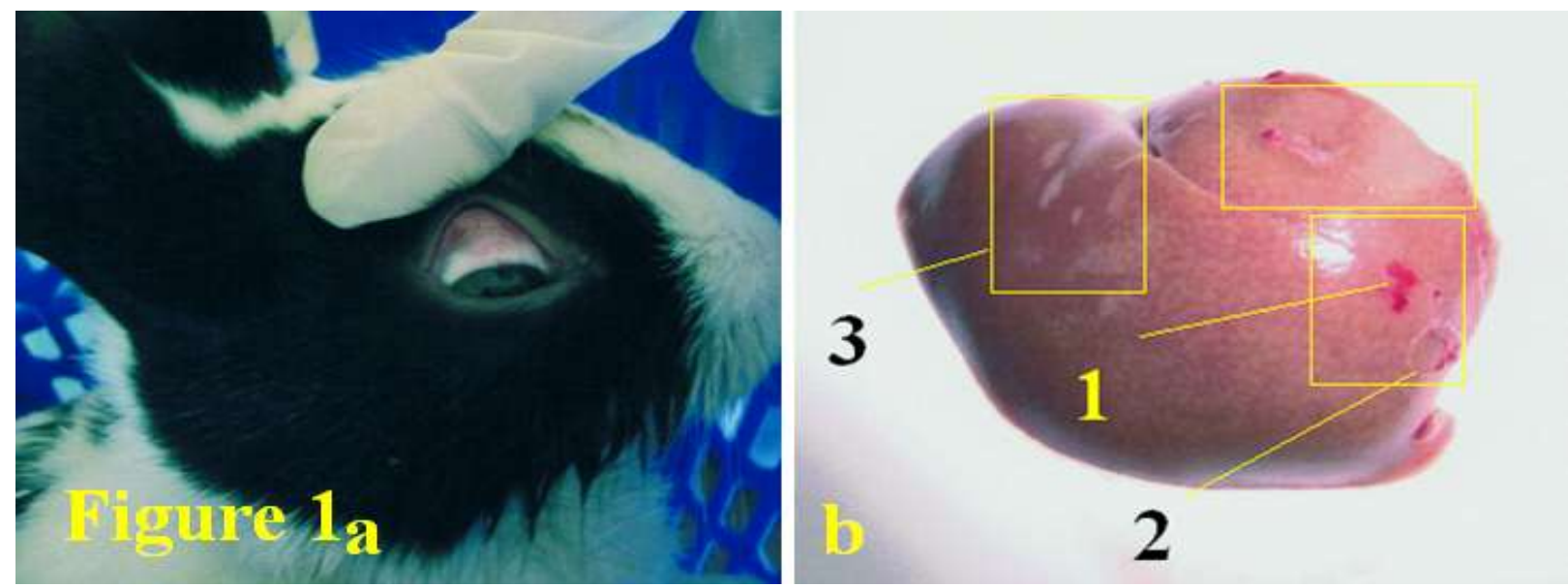

Figure (1 a): Congestion of conjunctiva and petechial hemorrhage. (b):Petechial hemorrhage (1), erosion in liver parenchyma(2) and patchy pale areas in liver parenchyma(3).

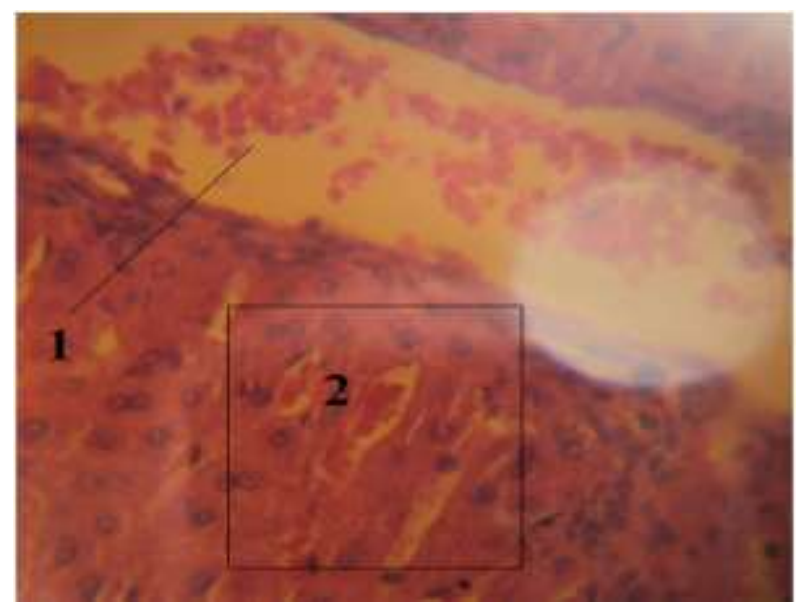

Figure (2) group A1: Engorgement of hepatic vein (1) and extravasated RBCs between the hepatocytes (2). (H\&E) 400X.

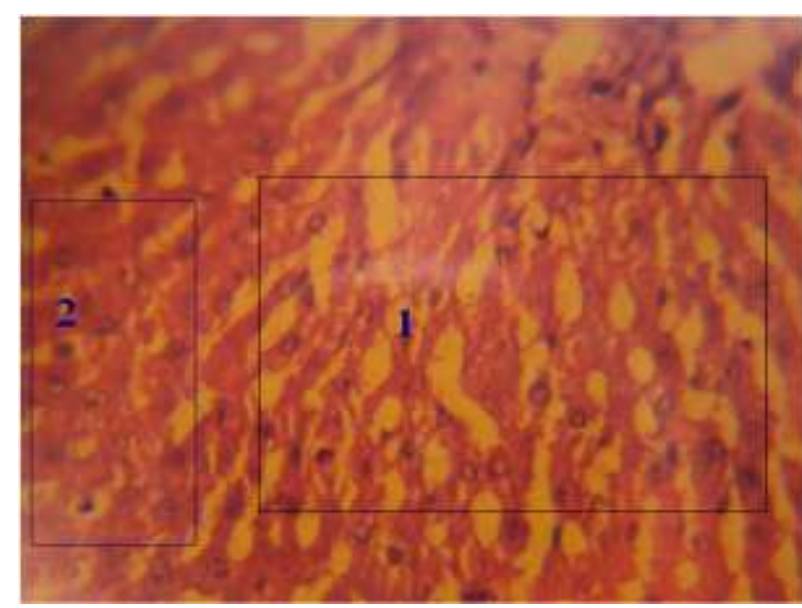

Figure (4) group A2: atrophy of hepatocytes (1), while (2) normal hepatocytes. (H\&E) 400X.

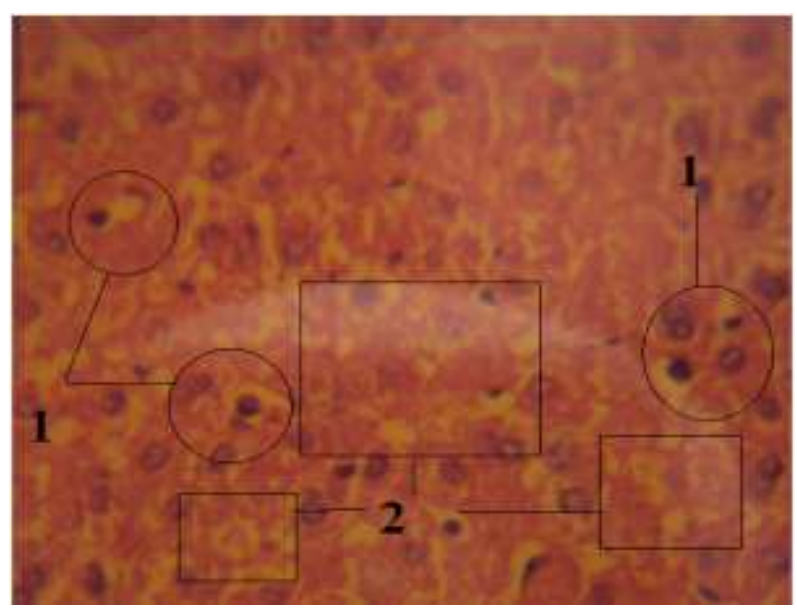

Figure (3) group A2: Infiltration of some polymorphnuclear leukocytes (1) and necrosis of hepatocytes (2). (H\&E) 400X.

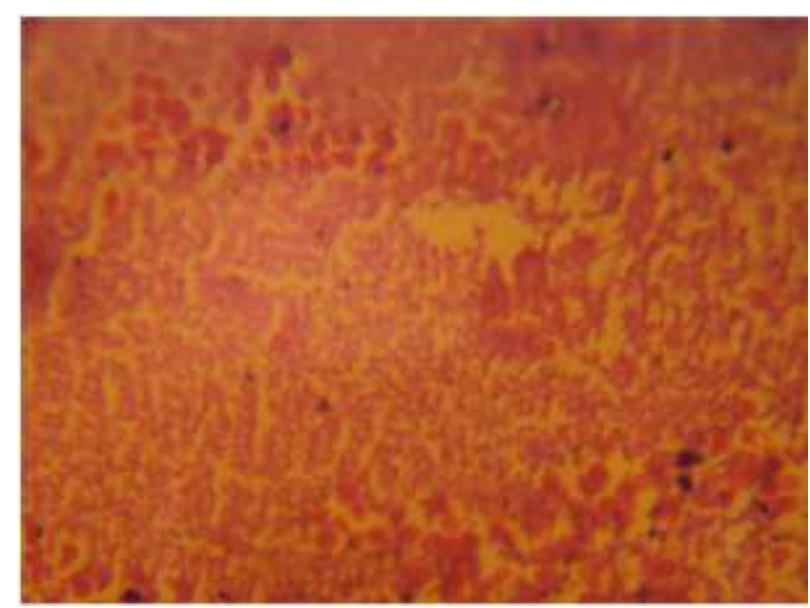

Figure (5) group A2: severely destructed hepatocytes (H\&E) 400X. 


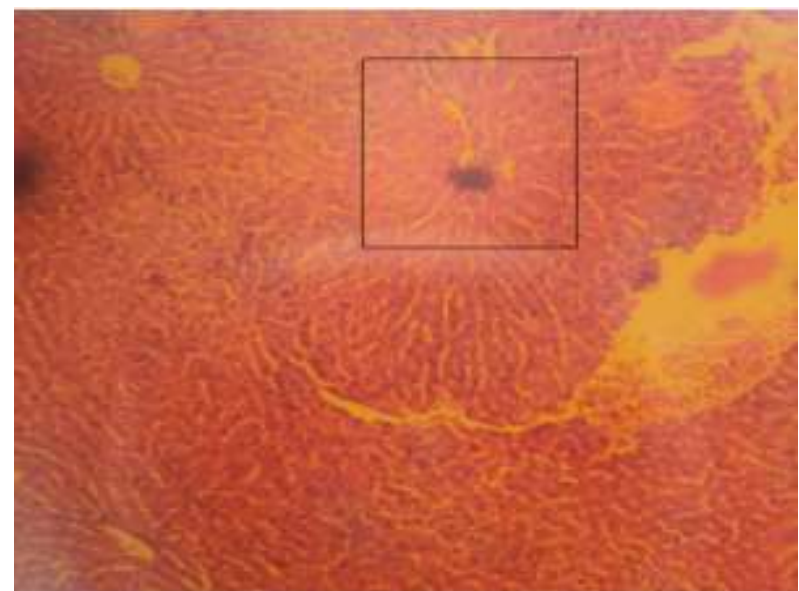

Figure (6) Group A2: engorgement of portal trait with bile secretion. (H\&E stain).100X (left figure) $400 \mathrm{X}$ (right figure).

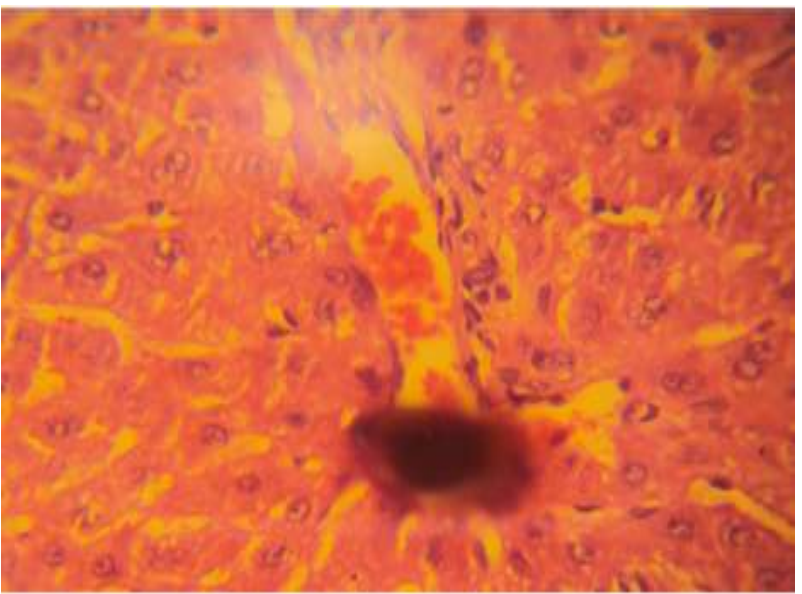

Figure (6) Group A2: engorgement of portal trait with bile secretion. (H\&E stain).100X (left figure) 400X (right figure).

\section{Discussion}

Pyrethroids tend to have more potent insecticidal properties, tend to be more toxic and more stable in the environment than naturally occurring pyrethrins , Although most pyrethrin and pyrethroid products are applied dermally, the natural grooming behavior of most animals results in oral and possibly inhalational exposures (1). In present study, most obvious clinical signs like Restlessness, salivation, licking of legs and face, frequent urination In addition, the recorded significant increase in heart rate and respiratory rate between treated groups and control group, petechial hemorrhage and congestion in the conjunctiva. The nerves signs like muscular tremor, incoordination, ataxia finely depression in treated groups in a dose dependent manner. Similar clinical signs have been recorded by different works with cypermethrin effects, These included salivation, muscular tremor, ataxia in rabbits (10) and restlessness, salvation recorded in dwarf goats (11), increased urination, licking of legs, jerky movement, ataxia, in coordination has been reported in rabbits (5); salivation, labored breathing and then CNS depression in rats (12); alphacypermethrin produce incoordination(13). The poisoning syndromes of type II pyrethroids produced (Choreoathetosis, with salivation) (CS), hyperexcitability and seizures $(14,15,16)$. Similarly (4) cypermethrin caused eye irritation. The main effects of pyrethroids are on sodium and chloride channels pyrethroids modify the gating characteristics of voltage sensitive sodium channels to delay their closure (17).The duration of sodium tail currents is much longer for type II pyrethroids the result membrane depolarization predominates in type II pyrethroids, The signs may be attributed to the disagreeable taste of the product or to a tingling sensation on the skin or oral mucous membranes (Paresthesia), is thought to result from direct action of pyrethroids on sensory nerve endings causing repetitive firing of these fiber (1). Type II pyrethroids also decrease chloride currents through voltage- dependent chloride channels and high concentrations can also act on GABA-gated chloride channels (17). The results of the present study indicated that cypermethrin induced anemia the significantly decrease in RBC counts, $\mathrm{Hb}$ concentration in treated groups and significantly decrease in PCV percentage in treated (A2) group, While the WBC counts revealed non significant decreased in treated groups compared with control group. Similarly, (5) reported anemia in rabbits because decrease in red blood cell counts and hemoglobin concentration due to the disruptive action of the pesticides on the erythropoietic tissue and might be affected of cell 
viability. Similarly, (18) showed that cypermethrin significantly decrease total erythrocyte counts, hemoglobin concentration, and PCV percentage. Similarly, (19) recorded a decrease in RBC counts, hemoglobin concentration and WBC counts this probably explained by effect of cypermethrin on the erythropoiesis, which is agreement with (20) high cypermethrin doses reduced the WBC count in peripheral blood. MCHC significantly decreased in all treated groups compared to control group while MCV non significantly increased in treated (A2) group compared with control. The increase in MCV and decrease in MCHC indicate macrocytic and hypochromic anemia. MCHC valves may be decreased in animals with regenerative anemia while increased MCV valves (Macrocytosis) are usually associated with regenerative anemia; macrocytosis is more likely to occur in response to hemolytic anemia (21). While and MCHC valves significantly difference between treated groups depended to dose used. Which is agreement with (22) showed significant decrease in total erythrocyte counts, hemoglobin concentration, and MCHC valves were found in the male rabbits treated intraperitoneally cypermethrin at higher doses. RDW (the red cell distribution width), RDW-CD and RDW$\mathrm{CV}$ valves as expressed as a percentage of mean erythrocyte volume significantly increased between (A1) and control group. It is often increased in regenerative anemia because reticulocytes and young erythrocytes are larger than mature erythrocytes (21).and also RDW-CV valves significantly difference between treated groups caused by the effects of cypermethrin depend on the dose. The platelet significantly decrease in (A2) group compared with control group, Which is agreement with (23) were recorded significant decrease of platelets which may be effect of pesticides these results could suggest that thrombocytopenia may be associated with disturbed production of platelet due to hypoplasia of bone marrow megacaryocytes. Histopathological study revealed that hepatocytes undergo atrophy and sever necrosis and destruction with infiltration of polymorph nuclear leucocytes dependent manner. Similarly, (24) were marked diffuse necrosis of hepatic tissue in all cypermethrin treated in rats. While the evident that cypermethrin produced hemorrhage and congestion were found in liver, agree with (12). In present study the significantly elevated plasma ALT, AST in treated (A1, A2) groups compared with control group, Is an indicator of tissue damage. Raised AST levels in rabbit can be found in association with liver disease (25).Induced biochemical changes correlate well with histopathological changes in liver. These result agree with (12) were recorded increased the activities of AST, ALT in rats treated with cypermethrin. The (26) were recorded that cypermethrin has toxic effect female hepatocytes and leakage of ALT, AST was significantly increased in a dose depended manner.

\section{Reference}

1. Volmer, P.A. (2004).Insecticides and Mollucicides (Pyrethrins and pyrethroids) In: Plumlee, k.(ed) Clinical veterinary toxicology, Mosby an affiliate of Elsevier, Philadelphia, USA,PP.188-192.

2.Wall, R. and Shearer, D. (2001). Veterinary Ectoparasites: Biology, Pathology and Control $\left(2^{\text {nd }}\right.$ Ed). Black well science Ltd, Oxford, London. pp: 183-184.
3. Taylor, M.A. (2004).Antiparastics In: Andrews, A.H., Blowey, R.W., Boyd, H. and Eddy, R.G. ( $2^{\text {nd }}$ Ed). Bovine Medicine Diseases and Husbandry of Cattle. Black well science Ltd, Oxford, UK, USA. pp: 1019-1034.

4. Cox, C. (1996). Insecticide fact sheet cypermethrin. Journal of Pesticide Reform/summer.16:1520. 
5. Shah, M.K., Khan, A., Rizvi, F., Siddique, M. and Sadeeq-urRehman.(2007). Effect of cypermethrin on clinicoHaematological parameters in rabbits. Pakistan Vet. J. 27 (4):171-175.

6. Anderson S.C. and Cockayne, S (1993): "Clinical Chemistry: Concepts and applications" Philadelphia, W.B. Saunders Company.pp:248264.

7. Evans, G.O. (2009).Animal clinical chemistry: A practical Guide for Toxicologists and Biomedical Researchers ( $2^{\text {nd }}$ ed) CRC Taylor and Francis group, Boca Raton, London, New York.pp.17-66.

8. Luna, L.G.(1968).Manual of Histologic staining Methods of the Armed Forces Institute of pathology, $3^{\text {rd }}$ ed., McGRAW-Hill Book Company., New York, Toronto, London.pp:1-38.

9. Chauhan, R.S. (2004): Veterinary Laboratory Diagnosis, $1^{\text {st }}$ Ed, International Book Distributing Co., Lucknow , pp: 269-285.

10. Ullah, M.S., Ahmad, M., Ahmad, N., Khan, M.Z. and Ahmad, I. (2006).Toxic effects of cypermethrin in female rabbits. Pakistan Vet. J. 26:193-196.

11. Khan, A., Faridi, H.A.M., Ali, M., Khan, M.Z., Siddique, M., Hussain, I. and Ahmad, M. (2009).Effects of cypermethrin on some clinico-hematobiochemical and pathological parameters in male dwarf goats (Capra hircus). Exp. Toxicol. Pathol.61:151-160.

12. Manna, S., Bhattacharyya, D., Basak, D.K. and Mandal, T.K. (2004).Single oral dose toxicity study of a-cypermethrin in rats. Indian J. Pharmocol. 36:25-28.

13. Wolansky, M.J. and Harrill, J.A. (2008). Neurobehavioral toxicology of pyrethroid insecticides in adult animals: a critical review (Abstract).
Neurotoxicol Teratol. Mar-Apr; 30:55-78.Epub 2007 Nov 17.

14. Ray, D.E., Ray, D. and Forshaw, P.J. (2000). Pyrethroid insecticides: Poisoning syndromes, Synergies, and therapy. Clinical Toxicology. 38:95-101.

15. Soderlund, D.M., Clark, J.M., Sheets, L.P., Mullin, L.S., Piccirillo, V.J., Sargent, D., Stevens, J.T. and Weiner, M.L. (2002). Mechanisms of pyrethroid neurotoxicity: implications for cumulative risk assessment.Toxicology.171:3-59.

16. Breckenridge, C.B.; Holden, L., Sturgess, N., Weiner, M., Sheets, L., Sargent, D., Soderlund D.M., Choi, J.S., Symington, S., Clark, J.M., Burr, S. and Ray, D. (2009). Evidence for aseparate mechanism of toxicity for the type I and type II pyrethroid insecticides (Abstract). Neurotoxicology. 2009, NOV; 30 Suppl 1:S17-31 Epub 2009 Sep 18.

17. Bradberry, S.M., Cage, S.A., Proudfoot, A.T. and Vale, J.A. (2005) Poisoning due to pyrethroids. Toxicol. Rev.24:93106.

18. Yousef, M.I., el-Demerdash, F.M., Kamel, K.I. and AL-Salhen, K.S. (2003). Changes in some hematological and biochemical indices of rabbits induced by isoflavones and cypermethrin. Toxicology. 189:223-234.

19. Dahamna, S., Harzallah, D., Guemache, A. and Sekfali, N. (2009). Biochemical investigation of cypermethrin toxicity in rabbits. Commun Agric. Appl.Biol.Sci. 74:149-153

20. Instito'ris, L., Undeger, U., Siroki, O., Nehe'z, M. and De'si, I.(1999).Comparison of detection sensitivity of immuno-and genotoxicological effects of subacute cypermethrin and 
permethrin exposure in rats.Toxicology.137:47-55.

21. Meyer, D.J. and Harvey, J.W. (2004).Veterinary Laboratory Medicine: Interpretation and Diagnosis $\left(3^{\text {rd }}\right.$ ed).Saunders. An imprint Elsevier inc., Philadelphia, USA. pp: 47-81.

22. Ahmad, L., Khan, A., Khan, M.Z. and Hussain, I. (2009). Cypermethrin induced anemia in male rabbits. Pakistan Vet.J.29:191-195.

23. Tokarska- Rodak, M., Tos'-Luty S. and Haratym-Maj A. (2004): Selected parameters of immunological response in hop growers during the period of intensive application of pesticides. Ann
Agric Environ Med 11: 227231.

24. Grewal, G., Verma, P.K., Dhar, V.J. and Srivastava, A.K. (2009). Toxicity of subacute oral administration of cypermethrin in rats with special reference to histopathological changes.I.J.G.P. 3:293-299.

25.Harcourt-Brown, N.H. (2002).Textbook of rabbit medicine (ed). Alden press, Oxford, Britain.pp:141-152.

26. El-Tawil, O.S. and Abdel-Rahman, M.S. (1997). Effect of cypermethrin on isolated male and female rat hepatocytes. Journal of Toxicology and Environmental Health, Part A.52:461-474.

\section{دراسة بعض الجوانب السمية للالفا سايبرمثرين في الاراتب

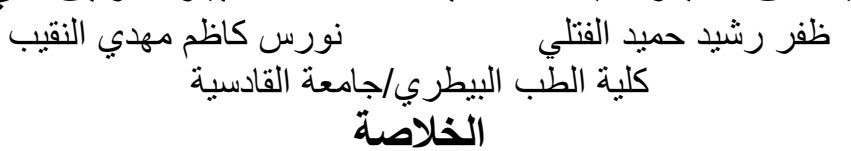

، اجريت هذه الدراسة لتقيم التغيرات الانية التي يحدثها التسم الحاد للسايبرمثرين cypermethrin وبجر التهر عة فموية

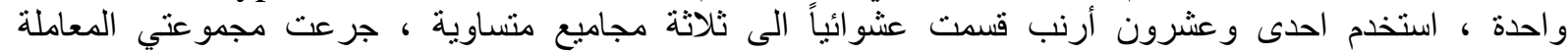
جرع فموية من الساييرمثرين (A2,A1)

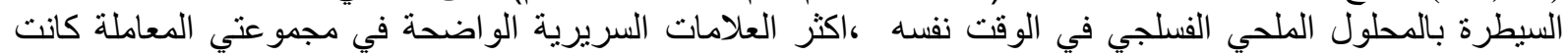

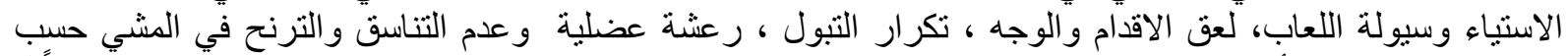

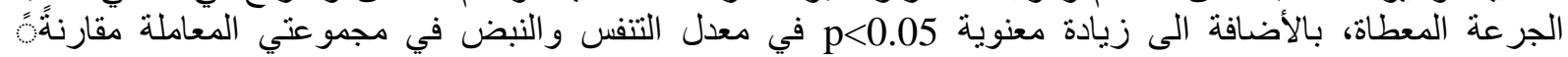

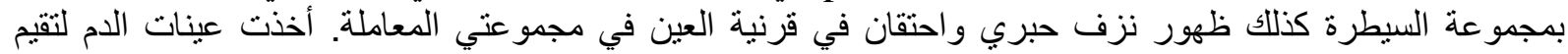

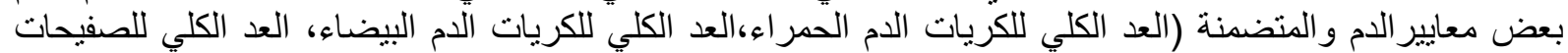

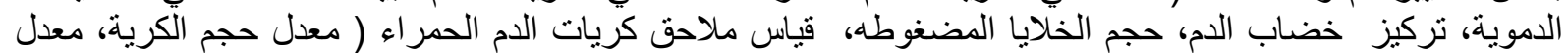

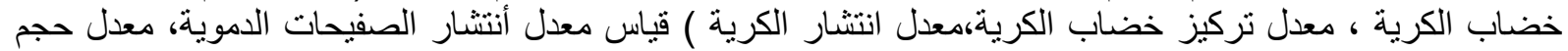

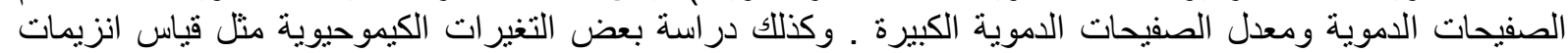

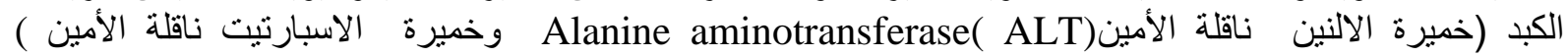
. Aspartate aminotransferase (AST)

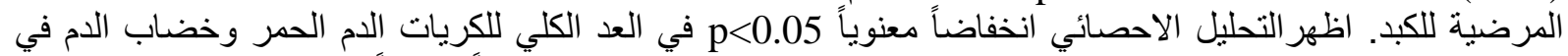

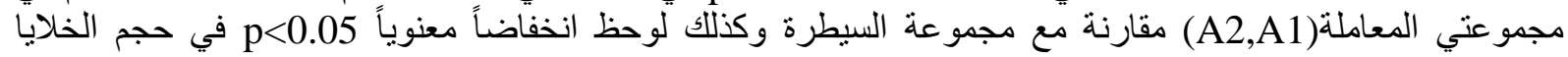

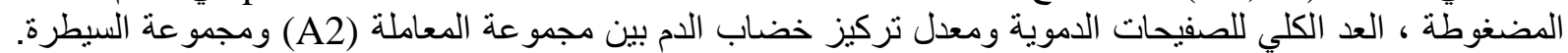

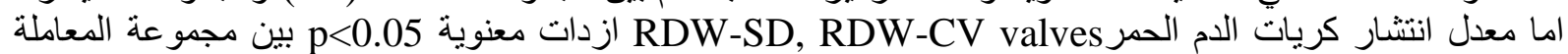

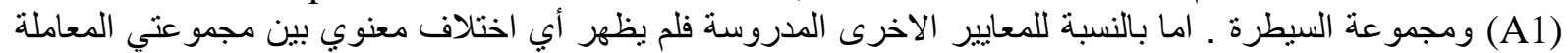

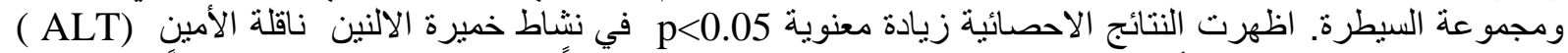

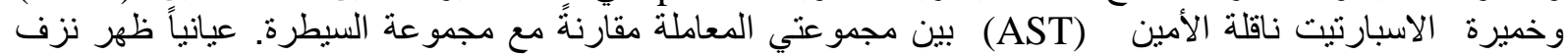

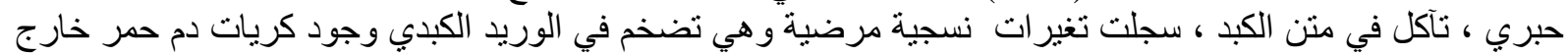

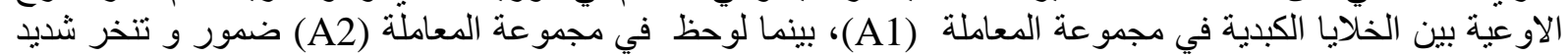

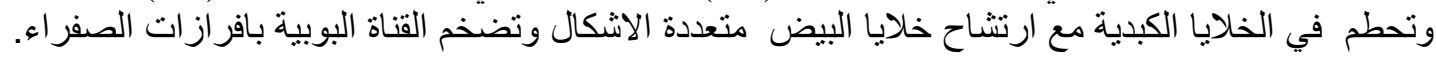

